\title{
OPEN Leaf proteome modulation and cytological features of seagrass Cymodocea nodosa in response to long-term high $\mathrm{CO}_{2}$ exposure in volcanic vents
}

\author{
Amalia Piro 1,5 , Letizia Bernardo ${ }^{2,5}$, Ilia Anna Serra ${ }^{1}$, Isabel Barrote ${ }^{3}$, Irene Olivé ${ }^{3,4}$, \\ Monya M. Costa ${ }^{3}$, Luigi Lucini ${ }^{2}$, Rui Santos ${ }^{3}$, Silvia Mazzuca ${ }^{1,5 \bowtie}$ \& João Silva ${ }^{3,5}$
}

Seagrass Cymodocea nodosa was sampled off the Vulcano island, in the vicinity of a submarine volcanic vent. Leaf samples were collected from plants growing in a naturally acidified site, influenced by the long-term exposure to high $\mathrm{CO}_{2}$ emissions, and compared with others collected in a nearby meadow living at normal $p \mathrm{CO}_{2}$ conditions. The differential accumulated proteins in leaves growing in the two contrasting $p \mathrm{CO}_{2}$ environments was investigated. Acidified leaf tissues had less total protein content and the semi-quantitative proteomic comparison revealed a strong general depletion of proteins belonging to the carbon metabolism and protein metabolism. A very large accumulation of proteins related to the cell respiration and to light harvesting process was found in acidified leaves in comparison with those growing in the normal $p \mathrm{CO}_{2}$ site. The metabolic pathways linked to cytoskeleton turnover also seemed affected by the acidified condition, since a strong reduction in the concentration of cytoskeleton structural proteins was found in comparison with the normal $p \mathrm{CO}_{2}$ leaves. Results coming from the comparative proteomics were validated by the histological and cytological measurements, suggesting that the long lasting exposure and acclimation of $C$. nodosa to the vents involved phenotypic adjustments that can offer physiological and structural tools to survive the suboptimal conditions at the vents vicinity.

The Mediterranean submarine volcanic vents are natural sources of $\mathrm{CO}_{2}$ since this gas is the main component of the volcanic emissions that have been happening for hundreds of years, forming unique and extraordinary environments in which the relative abundance of dissolved inorganic carbon $(\mathrm{Ci})$ species is altered by an increase in the partial pressure of $\mathrm{CO}_{2}\left(p \mathrm{CO}_{2}\right)$, with a consequent drastic reduction in seawater $\mathrm{pH}^{1,2}$. In these special acidic environments, marine ecosystems suffer from a drastic remodeling; while the pioneering studies on ocean acidification focused on how it negatively affects some species while favoring others ${ }^{3}$, more recent evidence exists on the large ecological effects on herbivores, invertebrates ${ }^{4-7}$ and on intra-community processes within seagrass meadows exposed to acidic conditions ${ }^{8,9}$. Seagrasses have been reported to be Ci-limited in the marine realm ${ }^{10-12}$, using $\mathrm{CO}_{2}$ and bicarbonate $\left(\mathrm{HCO}_{3}{ }^{-}\right)$as external $\mathrm{Ci}$ sources for photosynthesis ${ }^{10}$. Recent studies on ocean acidification have also aimed at resolving the question of whether seagrasses can fix an increasing amount of inorganic carbon $(\mathrm{Ci})$ in the future, thus providing a way forward to their survival while alleviating the effects a more acidic seawater in their associated ecosystems $\left({ }^{12}\right.$ and references therein, $\left.{ }^{13-16}\right)$.

Volcanic vents create, in the present, the necessary acidified conditions to evaluate the long-lasting effect of high $p \mathrm{CO}_{2}$ exposure on acclimated populations of marine plants, which is a mandatory requirement to understand the plant's real and sustained behavior ${ }^{17}$. Studies conducted in naturally acidified conditions at several

\footnotetext{
${ }^{1}$ Laboratory of Plant Biology and Plant Proteomics (Lab.Bio.Pro.Ve), Department of Chemistry and Chemical Technologies, Università della Calabria, Ponte Bucci 12 C, 87036 Rende, CS, Italy. ${ }^{2}$ Department of Sustainable Food Process, Università Cattolica Sacro Cuore, Via Emilia Parmense 84, 29122 Piacenza, Italy. ${ }^{3}$ CCMAR - Centre of Marine Sciences, University of Algarve, Campus of Gambelas, 8005-139 Faro, Portugal. ${ }^{4}$ Departamento de Biología, Facultad de Ciencias del Mar Y Ambientales, Universidad de Cádiz, Cádiz, Spain. ${ }^{5}$ These authors contributed equally: Amalia Piro, Letizia Bernardo, Silvia Mazzuca and João Silva. ${ }^{凶}$ email: silvia.mazzuca@ unical.it
} 


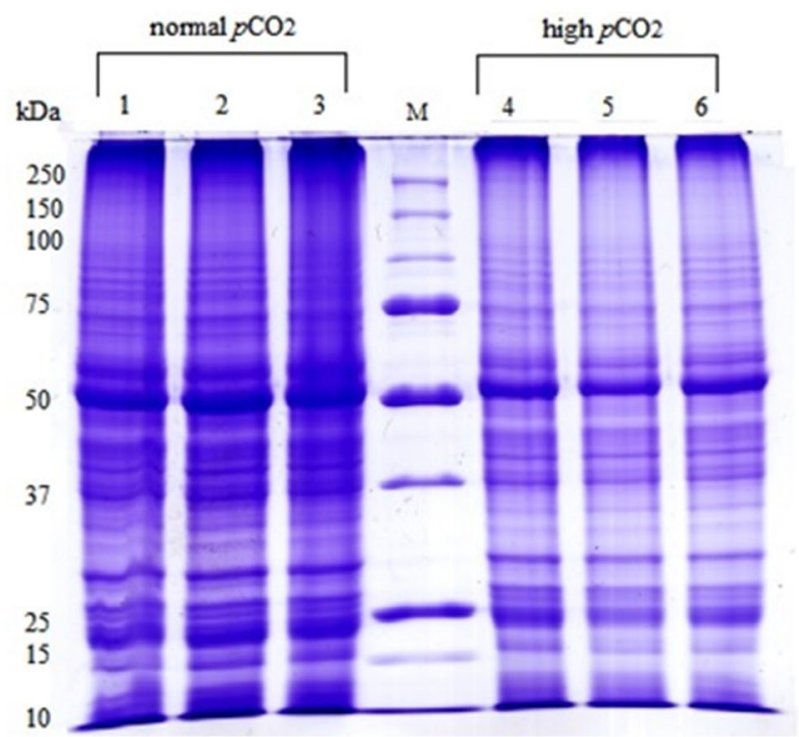

Figure 1. 1D-SDS PAGE of proteins from leaves of three biological replicates of Cymodocea nodosa living in normal (lanes 1,2,3) and in high (lanes 4,5,6) $p \mathrm{CO}_{2}$ environments in Vulcano Island. $25 \mu \mathrm{g}$ of proteins in each well were loaded. Markers used from Bio-Rad 250-10 kDa.

volcanic sites have provided contrasting results, often suggesting species-specific responses to increased $p \mathrm{CO}_{2}{ }^{8,9,18}$. An ecological assessment of Cymodocea nodosa at a shallow acidified site at Volcano Island (Italy) revealed that the meadow is negatively affected by the environmental conditions at the low $\mathrm{pH}$ site, as the plant's density and biomass decreased ${ }^{8,9}$; authors also reported a decrease in leaf area in plants acclimated to the $\mathrm{CO}_{2}$ vents. This latter finding, along with similar studies, strongly suggests that the acclimation of seagrasses to the long-lasting high $p \mathrm{CO}_{2}$ concentration encompasses several physiological and morphological adjustments. It is relevant to note that some biomechanical responses of $C$. nodosa were altered in the course of a $\mathrm{CO}_{2}$ enrichment experiment ${ }^{19}$ and that changes in plant anatomy and cell ultrastructure have been reported for Halodule wrightii under ocean acidification conditions ${ }^{20}$. These observations are in line to those previously observed in terrestrial plants, in which the exposure to high $p \mathrm{CO}_{2}$ induced several anatomical alterations ${ }^{21-23}$.

On the molecular side, a wider investigation on the gene expression profile, performed in the same population of Cymodocea nodosa in Vulcano island, confirmed the decrease in productivity in plants growing at the high $\mathrm{CO}_{2}$ site $^{24}$. Contrastingly, the same study reported that productivity significantly increased with Ci availability in plants incubated with artificially $\mathrm{CO}_{2}$-enriched water at a non-acidified control site, supporting the hypothesis that $C$. nodosa might in general benefit from a higher $\mathrm{Ci}$ availability ${ }^{24,25}$. Taken all together, these results support the suggestion that volcanic vents may not be ideal analogues for ocean acidification studies and that the observed effects on seagrasses are not merely due to the increased $\mathrm{CO}_{2}$ availability but are also influenced by other environmental factors present at these sites ${ }^{9}$.

In this controversial scenario, our study aims to elucidate how a well-established natural population of Cymodocea nodosa, exposed to the $\mathrm{CO}_{2}$ vents environment at Vulcano Island, modulates its protein metabolism and what specific modifications take place, both at the morphological and functional traits levels, associated to the long-term adaptation process.

Comparative proteomics has been previously applied to seagrasses, revealing the protein molecular dynamics for surviving under various conditions ${ }^{26-30}$ Since the amounts of protein and transcripts corresponding to the same gene are generally loosely correlated ${ }^{31}$, the advantage offered by proteomics in the present study is to reveal changes in protein accumulation induced by high $\mathrm{CO}_{2}$ that cannot have been predicted from the previous transcriptomics investigation ${ }^{24}$, thus contributing to elucidate the effects of a long-term exposure to naturally increased $p \mathrm{CO}_{2}$.

\section{Results}

Protein yield, proteins identification and differential accumulated proteins in leaf tissues. A decrease of $30 \%$ in protein yield in leaf tissues of plants growing in high $p \mathrm{CO}_{2}$ comparing to the normal $p \mathrm{CO}_{2}$ condition was found (See the Supplementary Table 1). The SDS-PAGEs of leaf proteins provided well-resolved lanes both in normal and high $p \mathrm{CO}_{2}$ samples. Each lane consists of about 80 different polypeptides bands, demonstrating the efficiency of the protein extraction and purification by means of the multistep protocol optimized for C. nodosa $a^{28}$. Spite the same amount of leaf proteins loaded on each well, the band at $55 \mathrm{kDa}$, corresponding to the large subunit of RuBisCo, decreased in all replicates of plants living in high $p \mathrm{CO}_{2}$ with respect to those under normal $p \mathrm{CO}_{2}$ condition (Fig. 1). Measures from the digitalized images of the gels by the Quantity One 1-D Analysis Software (Bio-Rad Laboratories; Berkley, California) gave a mean decrease of up to $40 \%$ in the optical density of the $55 \mathrm{kDa}$ band (data not shown) in the high $p \mathrm{CO}_{2}$ samples. 


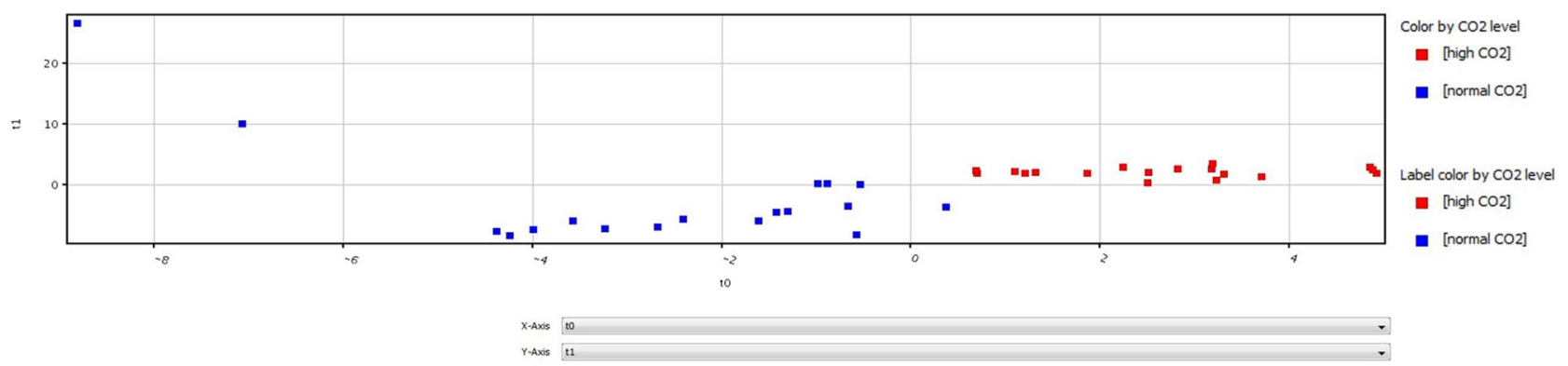

Figure 2. Multivariate classification (PLS-DA) predictions (Mass Profiler Professional Software) of full mass spectra results from normal $p \mathrm{CO}_{2}$ (blue box) and high $p \mathrm{CO}_{2}$ (red box) C. nodosa samples (All mass spectra of all samples). Horizontal dashed lines indicate the thresholds and vertical dashed lines indicate the separation between samples.

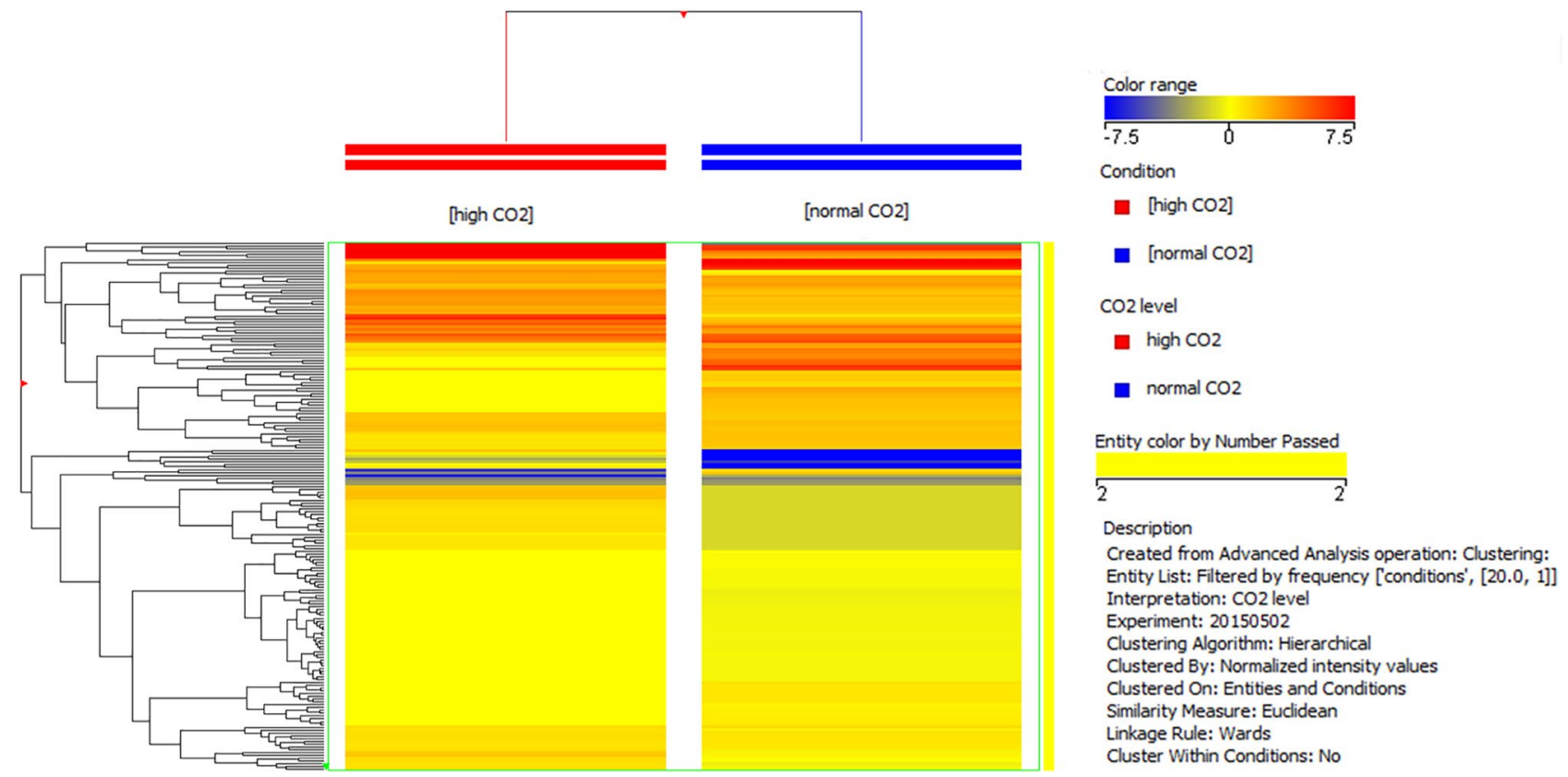

Figure 3. Hierarchical clustering of all proteins identified in the normal $p \mathrm{CO}_{2}$ and in the high $p \mathrm{CO}_{2}$ samples.

Figure 2 depicts the multivariate classification (PLS-DA) of all mass spectra results from normal $p \mathrm{CO}_{2}$ and high $p \mathrm{CO}_{2}$ plants. Spectra patterns of normal (blue dots) and high (red dots) $p \mathrm{CO}_{2}$ plants are quite distinct. Plants collected in high $p \mathrm{CO}_{2}$ showed a higher degree of homogeneity in comparison to samples collected in normal $p \mathrm{CO}_{2}$.

The mass spectra analysis coupled with database search has identified 190 proteins in all samples (Supplementary Tables 2 and 3). The hierarchical clustering of all identified proteins is shown in Fig. 3. Under the screening criteria of a fold change greater than 2 or less than 0.60 and $p$ value $<0.05$, a total of 75 proteins were identified to be differentially abundant (DAPs) by comparison between normal $p \mathrm{CO}_{2}$ and high $p \mathrm{CO}_{2}$ plants; 45 proteins resulted accumulated, while the remaining 30 proteins are depleted. All these proteins were regarded as candidate proteins associated with the high $p \mathrm{CO}_{2}$ adaptation and acclimation processes (Table 1).

The pathway analysis using the Kyoto Encyclopedia of Genes and Genomes (KEGG) pathway database ${ }^{32}$ (http://www.genome.jp/kegg/pathway.html, accessed on 11 September 2019) identified 6 pathways $(\mathrm{p}<0.05)$ related to proteins with enriched relative abundance, as shown in Fig. 4. Proteins involved in the light reactions of photosynthesis are the most relevantly enriched under the acidified conditions. These include the Photosystem II CP43 chlorophyll apoprotein, Photosystem II D2 protein, Photosystem II CP47 chlorophyll apoprotein, Photosystem Q(B) protein, Photosystem I P700 chlorophyll a apoprotein A2, ATP synthase subunit beta, chloroplastic, Cytochrome b6, ATP synthase subunit alpha and the chloroplastic Photosystem I P700 chlorophyll a apoprotein A1 (Table 1). In contrast, the depleted metabolic pathways were those related to carbon fixation, carbon metabolism, glycolysis/gluconeogenesis. The Ribulose bisphosphate carboxylase large chain and the Ribulose bisphosphate carboxylase/oxygenase activase appeared strongly depleted in acidified conditions, as also cytoplasmic and chloroplastic Malate dehydrogenase and Transketolase. The key enzymes of glycolysis 


\begin{tabular}{|c|c|c|c|c|c|c|c|c|}
\hline Swiss-Prot ID & $\begin{array}{l}\text { KEGG }^{*} \text { orthology } \\
\text { (proteins) }\end{array}$ & Protein & $\begin{array}{l}\text { Log FC ([high } \\
\text { CO2] versus } \\
\text { [normal CO2]) } \\
\text { Normalized }\end{array}$ & $\begin{array}{l}\text { FC (abs) ([high } \\
\text { CO2] versus } \\
\text { [normal CO2]) } \\
\text { Normalized }\end{array}$ & \begin{tabular}{|l|} 
DAPs ([high \\
CO2] versus \\
[normal CO2]) \\
Normalized
\end{tabular} & $\begin{array}{l}\text { Molecular Mass } \\
\text { (Da) }\end{array}$ & $\begin{array}{l}\text { KEGG* }^{*} \\
\text { orthology } \\
\text { (metabolisms) }\end{array}$ & Metabolism \\
\hline P0C365 & K02705 & $\begin{array}{l}\text { Photosystem II } \\
\text { CP43 chlorophyll } \\
\text { apoprotein }\end{array}$ & 13.134 & 8993.973 & STA & $52,246.3$ & ko00195 & Photosynthesis \\
\hline P0C435 & K02706 & $\begin{array}{l}\text { Photosystem II D2 } \\
\text { protein }\end{array}$ & 12.430 & 5520.685 & STA & $39,801.0$ & ko00195 & Photosynthesis \\
\hline P05641 & K02704 & $\begin{array}{l}\text { Photosystem II } \\
\text { CP47 chlorophyll } \\
\text { apoprotein }\end{array}$ & 10.513 & 1461.336 & STA & $56,276.2$ & ko00195 & Photosynthesis \\
\hline P0C432 & K02703 & $\begin{array}{l}\text { Photosystem Q(B) } \\
\text { protein }\end{array}$ & 8.324 & 320.653 & STA & $39,076.0$ & ko00195 & Photosynthesis \\
\hline P05642 & K02635 & Cytochrome b6 & 7.938 & 245.255 & STA & $24,310.3$ & ko00195 & Photosynthesis \\
\hline P19023 & K02133 & $\begin{array}{l}\text { ATP synthase } \\
\text { subunit beta, } \\
\text { mitochondrial }\end{array}$ & 7.155 & 142.595 & STA & $59,216.4$ & ko00190 & $\begin{array}{l}\text { Energy metabo- } \\
\text { lism }\end{array}$ \\
\hline P00827 & K02112 & $\begin{array}{l}\text { ATP synthase } \\
\text { subunit beta, } \\
\text { chloroplastic }\end{array}$ & 6.426 & 86.00222 & STA & $54,097.0$ & ko00195 & Photosynthesis \\
\hline P0C387 & K02634 & Apocytochrome f & 6.121 & 69.602 & STA & $35,580.5$ & ko00195 & Photosynthesis \\
\hline A5H454 & K00432 & Peroxidase 66 & 5.701 & 52.048 & STA & $33,932.3$ & ko01100 & Lipid metabolism \\
\hline P0C356 & K02690 & $\begin{array}{l}\text { Photosystem I } \\
\text { P700 chlorophyll a } \\
\text { apoprotein A2 }\end{array}$ & 4.901 & 29.885 & STA & $82,672.8$ & ko00195 & Photosynthesis \\
\hline P12863 & K01803 & $\begin{array}{l}\text { Triosephosphate } \\
\text { isomerase, } \\
\text { cytosolic }\end{array}$ & 4.827 & 28.386 & STA & $27,252.6$ & ko00010 & $\begin{array}{l}\text { Glycolysis/Gluco- } \\
\text { neogenesis }\end{array}$ \\
\hline $\mathrm{O} 24592$ & K09840 & $\begin{array}{l}\text { 9-cis-epoxycarot- } \\
\text { enoid dioxygenase } \\
1, \text { chloroplastic }\end{array}$ & 4.805 & 27.953 & STA & $66,007.5$ & ko01110 & $\begin{array}{l}\text { Biosynthesis of } \\
\text { seconday metabo- } \\
\text { lites }\end{array}$ \\
\hline P0C2Z4 & K02111 & $\begin{array}{l}\text { ATP synthase } \\
\text { subunit alpha, } \\
\text { chloroplastic }\end{array}$ & 4.095 & 17.091 & STA & $55,721.0$ & ko00195 & Photosynthesis \\
\hline P0С353 & K02689 & $\begin{array}{l}\text { Photosystem I } \\
\text { P700 chlorophyll a } \\
\text { apoprotein A1 }\end{array}$ & 3.406 & 10.603 & STA & $83,395.2$ & ko00195 & Photosynthesis \\
\hline Q41764 & K10363 & $\begin{array}{l}\text { Actin-depolymer- } \\
\text { izing factor } 3\end{array}$ & 2.982 & 7.905 & A & $16,013.8$ & ko04812 & $\begin{array}{l}\text { Signaling and cel- } \\
\text { lular processes }\end{array}$ \\
\hline Q8W2B7 & K13227 & $\begin{array}{l}\text { DIMBOA UDP- } \\
\text { glucosyltrans- } \\
\text { ferase BX8 }\end{array}$ & 2.981 & 7.895 & A & $49,926.0$ & ko00402 & $\begin{array}{l}\text { Biosynthesis of } \\
\text { seconday metabo- } \\
\text { lites }\end{array}$ \\
\hline P46302 & K02979 & $\begin{array}{l}40 \mathrm{~S} \text { ribosomal } \\
\text { protein S28 }\end{array}$ & 2.980 & 7.889 & A & $7,467.6$ & ko03010 & Translation \\
\hline A1Y2B7 & no KO assigned & $\begin{array}{l}\text { Protein SUPPRES- } \\
\text { SOR OF GENE } \\
\text { SILENCING } 3\end{array}$ & 2.933 & 7.640 & A & $67,979.5$ & no KO assigned & $\begin{array}{l}\text { No assigned } \\
\text { metabolism }\end{array}$ \\
\hline P46252 & K02943 & $\begin{array}{l}\text { 60S acidic riboso- } \\
\text { mal protein P2A }\end{array}$ & 2.763 & 6.790 & A & $11,476.7$ & ko03010 & Translation \\
\hline Q00827 & K08912 & $\begin{array}{l}\text { Chlorophyll a-b } \\
\text { binding protein } \\
48 \text {, chloroplastic }\end{array}$ & 2.675 & 6.386 & A & $28,299.8$ & ko00195 & Photosynthesis \\
\hline A5H452 & K00432 & Peroxidase 70 & 2.449 & 5.462 & A & $33,994.0$ & ko01100 & Lipid metabolism \\
\hline Q9FQA3 & K00799 & $\begin{array}{l}\text { Glutathione trans- } \\
\text { ferase GST } 23\end{array}$ & 2.327 & 5.018 & A & $24,992.4$ & ko00480 & $\begin{array}{l}\text { Glutathione } \\
\text { metabolism }\end{array}$ \\
\hline B4FGS2 & no KO assigned & $\begin{array}{l}\text { Spindle and } \\
\text { kinetochore-asso- } \\
\text { ciated protein } 1 \\
\end{array}$ & 2.254 & 4.769 & A & $30,488.3$ & no KO assigned & $\begin{array}{l}\text { No assigned } \\
\text { metabolism }\end{array}$ \\
\hline B6TZD1 & K08963 & $\begin{array}{l}\text { Methylthioribose- } \\
\text { 1-phosphate } \\
\text { isomerase }\end{array}$ & 2.205 & 4.613 & A & $38,735.5$ & ko00270 & $\begin{array}{l}\text { Amino acid } \\
\text { metabolism }\end{array}$ \\
\hline P46420 & K00799 & \begin{tabular}{|l|} 
Glutathione \\
S-transferase 4
\end{tabular} & 2.178 & 4.524 & A & $24,741.1$ & ko00480 & $\begin{array}{l}\text { Glutathione } \\
\text { metabolism }\end{array}$ \\
\hline P11155 & K20115 & $\begin{array}{l}\text { Pyruvate, phos- } \\
\text { phate dikinase } 1, \\
\text { chloroplastic }\end{array}$ & 2.143 & 4.416 & A & $103,585.5$ & ko00710 & Carbon fixation \\
\hline P49101 & K06103 & $\begin{array}{l}\text { Calcium- } \\
\text { dependent protein } \\
\text { kinase } 2\end{array}$ & 2.139 & 4.405 & A & $58,422.9$ & ko04131 & Exocytosis \\
\hline B8A031 & K03644 & $\begin{array}{l}\text { Lipoyl synthase, } \\
\text { mitochondrial }\end{array}$ & 2.126 & 4.366 & A & $42,341.6$ & ko01100 & Lipid metabolism \\
\hline
\end{tabular}




\begin{tabular}{|c|c|c|c|c|c|c|c|c|}
\hline Swiss-Prot ID & $\begin{array}{l}\text { KEGG }^{*} \text { orthology } \\
\text { (proteins) }\end{array}$ & Protein & $\begin{array}{l}\text { Log FC ([high } \\
\text { CO2] versus } \\
\text { [normal CO2]) } \\
\text { Normalized }\end{array}$ & $\begin{array}{l}\text { FC (abs) ([high } \\
\text { CO2] versus } \\
\text { [normal CO2]) } \\
\text { Normalized }\end{array}$ & $\begin{array}{l}\text { DAPs ([high } \\
\text { CO2] versus } \\
\text { [normal CO2]) } \\
\text { Normalized }\end{array}$ & $\begin{array}{l}\text { Molecular Mass } \\
\text { (Da) }\end{array}$ & $\begin{array}{l}\begin{array}{l}\text { KEGG }^{*} \\
\text { orthology } \\
\text { (metabolisms) }\end{array} \\
\end{array}$ & Metabolism \\
\hline P49094 & K01953 & \begin{tabular}{|l|} 
Asparagine \\
synthetase \\
[glutamine-hydro- \\
lyzing]
\end{tabular} & 2.126 & 4.364 & A & $67,147.1$ & ko00270 & $\begin{array}{l}\text { Amino acid } \\
\text { metabolism }\end{array}$ \\
\hline Р0С $8 \mathrm{M} 8$ & K08852 & $\begin{array}{l}\text { serine/threonine- } \\
\text { protein kinase } \\
\text { CCRP1 }\end{array}$ & 2.062 & 4.176 & A & $70,746.2$ & ko04141 & $\begin{array}{l}\text { Protein processing } \\
\text { in endoplasmic } \\
\text { reticulum }\end{array}$ \\
\hline O63066 & K10956 & $\begin{array}{l}\text { Preprotein } \\
\text { translocase } \\
\text { subunit SECY, } \\
\text { chloroplastic }\end{array}$ & 2.031 & 4.086 & A & $59,637.9$ & ko04141 & $\begin{array}{l}\text { Protein processing } \\
\text { in endoplasmic } \\
\text { reticulum }\end{array}$ \\
\hline Q8LPU4 & K11303 & $\begin{array}{l}\text { Histone acetyl- } \\
\text { transferase type B } \\
\text { catalytic subunit }\end{array}$ & 2.028 & 4.079 & A & $53,119.5$ & ko03400 & DNA repair \\
\hline C0PF72 & K00620 & $\begin{array}{l}\text { Arginine biosyn- } \\
\text { thesis bifunctional } \\
\text { protein ArgJ, } \\
\text { chloroplastic }\end{array}$ & 2.016 & 4.046 & A & $48,407.3$ & ko01230 & $\begin{array}{l}\text { Amino acids } \\
\text { biosynthesis }\end{array}$ \\
\hline Q67EU8 & K04482 & $\begin{array}{l}\text { DNA repair } \\
\text { protein RAD51 } \\
\text { homolog A }\end{array}$ & 1.998 & 3.994 & SLA & $36,989.5$ & ko03400 & DNA repair \\
\hline Q10717 & K16290 & $\begin{array}{l}\text { Cysteine protein- } \\
\text { ase } 2\end{array}$ & 1.976 & 3.935 & SLA & $39,712.1$ & ko01002 & $\begin{array}{l}\text { Protein degrada- } \\
\text { tion }\end{array}$ \\
\hline P41978 & K04564 & $\begin{array}{l}\text { Superoxide dis- } \\
\text { mutase }[\mathrm{Mn}] 3.2 \text {, } \\
\text { mitochondrial }\end{array}$ & 1.914 & 3.770 & SLA & $25,356.4$ & ko04146 & Oxidative stress \\
\hline P42390 & K13222 & $\begin{array}{l}\text { Indole-3-glycerol } \\
\text { phosphate lyase, } \\
\text { chloroplastic }\end{array}$ & 1.888 & 3.701 & SLA & $36,691.8$ & ko00402 & $\begin{array}{l}\text { Biosynthesis sec- } \\
\text { onday metabolites }\end{array}$ \\
\hline P00056 & K00413 & Cytochrome c & 1.885 & 3.695 & SLA & $12,132.6$ & ko00190 & $\begin{array}{l}\text { Energy metabo- } \\
\text { lism }\end{array}$ \\
\hline P49081 & K01638 & $\begin{array}{l}\text { Malate synthase, } \\
\text { glyoxysomal }\end{array}$ & 1.881 & 3.684 & SLA & $62,092.2$ & ko01200 & $\begin{array}{l}\text { Carbon metabo- } \\
\text { lism }\end{array}$ \\
\hline Q9XGD5 & K00588 & $\begin{array}{l}\text { Caffeoyl-CoA } \\
\text { O-methyltrans- } \\
\text { ferase } 2\end{array}$ & 1.851 & 3.607 & SLA & $29,522.0$ & ko01110 & $\begin{array}{l}\text { Biosynthesis of } \\
\text { secondary metabo- } \\
\text { lites }\end{array}$ \\
\hline P12959 & K21632 & $\begin{array}{l}\text { Regulatory protein } \\
\text { opaque-2 }\end{array}$ & 1.815 & 3.519 & SLA & $49,812.2$ & ko03000 & Transcription \\
\hline P23345 & K04565 & \begin{tabular}{|l|} 
Superoxide \\
dismutase $[\mathrm{Cu}-$ \\
$\mathrm{Zn}] 4 \mathrm{~A}$
\end{tabular} & 1.593 & 3.017 & SLA & $15,228.5$ & ko04146 & Oxidativ stress \\
\hline Q05737 & K07874 & $\begin{array}{l}\text { GTP-binding } \\
\text { protein YPTM2 }\end{array}$ & 1.558 & 2.945 & SLA & $22,646.2$ & ko04031 & Protein transport \\
\hline P06671 & K08913 & $\begin{array}{l}\text { Chlorophyll a-b } \\
\text { binding protein, } \\
\text { chloroplastic }\end{array}$ & 1.427 & 2.689 & SLA & $28,165.7$ & ko00195 & Photosynthesis \\
\hline P0C520 & K02132 & $\begin{array}{l}\text { ATP synthase } \\
\text { subunit alpha, } \\
\text { mitochondrial }\end{array}$ & 1.414 & 2.665 & SLA & $55,657.7$ & ko00190 & $\begin{array}{l}\text { Energy metabo- } \\
\text { lism }\end{array}$ \\
\hline Q41803 & K03231 & $\begin{array}{l}\text { Elongation factor } \\
\text { 1-alpha }\end{array}$ & -7.805 & 223.659 & STD & $49,574.4$ & ko03013 & Translation \\
\hline Q08062 & K00025 & $\begin{array}{l}\text { Malate dehydroge- } \\
\text { nase, cytoplasmic }\end{array}$ & -7.712 & 209.621 & STD & $35,931.6$ & ko01200 & $\begin{array}{l}\text { Carbon metabo- } \\
\text { lism }\end{array}$ \\
\hline P0C510 & K01601 & $\begin{array}{l}\text { Ribulose bisphos- } \\
\text { phate carboxylase } \\
\text { large chain }\end{array}$ & -7.099 & 137.062 & STD & $53,450.7$ & ko00710 & Carbon fixation \\
\hline Q43298 & K04077 & $\begin{array}{l}\text { Chaperonin } \\
\text { CPN60-2, mito- } \\
\text { chondrial }\end{array}$ & -6.089 & 68.074 & STD & $61,219.3$ & ko03018 & Protein folding \\
\hline P27923 & K02977 & $\begin{array}{l}\text { Ubiquitin- } 40 \text { S } \\
\text { ribosomal protein } \\
\text { S27a }\end{array}$ & -5.271 & 38.628 & STD & $17,909.5$ & hsa03010 & Translation \\
\hline P14640 & K07374 & $\begin{array}{l}\text { Tubulin alpha-1 } \\
\text { chain }\end{array}$ & -4.601 & 24.271 & STD & $50,414.8$ & ko04514 & $\begin{array}{l}\text { Citoskeleton } \\
\text { metabolism }\end{array}$ \\
\hline Q02245 & K07374 & $\begin{array}{l}\text { Tubulin alpha-5 } \\
\text { chain }\end{array}$ & -4.556 & 23.538 & STD & $50,251.7$ & ko04514 & $\begin{array}{l}\text { Citoskeleton } \\
\text { metabolism }\end{array}$ \\
\hline Q9ZT00 & K19199 & $\begin{array}{l}\text { Ribulose bisphos- } \\
\text { phate carboxylase/ } \\
\text { oxygenase acti- } \\
\text { vase, chloroplastic }\end{array}$ & -4.483 & 22.367 & STD & $48,108.8$ & ko00710 & Carbon fixation \\
\hline
\end{tabular}




\begin{tabular}{|c|c|c|c|c|c|c|c|c|}
\hline Swiss-Prot ID & $\begin{array}{l}\text { KEGG }^{*} \text { orthology } \\
\text { (proteins) }\end{array}$ & Protein & \begin{tabular}{|l} 
Log FC ([high \\
CO2] versus \\
[normal CO2]) \\
Normalized \\
\end{tabular} & $\begin{array}{l}\text { FC (abs) ([high } \\
\text { CO2] versus } \\
\text { [normal CO2]) } \\
\text { Normalized } \\
\end{array}$ & \begin{tabular}{|l|} 
DAPs ([high \\
CO2] versus \\
[normal CO2]) \\
Normalized \\
\end{tabular} & $\begin{array}{l}\text { Molecular Mass } \\
\text { (Da) }\end{array}$ & \begin{tabular}{|l|l}
$\begin{array}{l}\text { KEGG }^{*} \\
\text { orthology } \\
\text { (metabolisms) }\end{array}$ \\
\end{tabular} & Metabolism \\
\hline P09315 & K05298 & \begin{tabular}{|l|} 
Glyceraldehyde- \\
3-phosphate \\
dehydrogenase A, \\
chloroplastic \\
\end{tabular} & -4.386 & 20.907 & STD & $43,208.4$ & ko00010 & $\begin{array}{l}\text { Glycolysis/Gluco- } \\
\text { neogenesis }\end{array}$ \\
\hline Q7SIC9 & K00615 & \begin{tabular}{|l|}
$\begin{array}{l}\text { Transketolase, } \\
\text { chloroplastic }\end{array}$ \\
\end{tabular} & -4.094 & 17.078 & STD & $73,391.4$ & ko01200 & $\begin{array}{l}\text { Carbon metabo- } \\
\text { lism }\end{array}$ \\
\hline P24631 & K13993 & $\begin{array}{l}17.5 \mathrm{kDa} \text { class II } \\
\text { heat shock protein }\end{array}$ & -3.6320088 & 12.398 & STD & $17,568.0$ & ko04141 & $\begin{array}{l}\text { Protein processing } \\
\text { in endoplasmic } \\
\text { reticulum }\end{array}$ \\
\hline P08440 & K01623 & $\begin{array}{l}\text { Fructose-bispho- } \\
\text { sphate aldolase, } \\
\text { cytoplasmic }\end{array}$ & -3.430 & 10.778 & STD & $39,059.9$ & ko00010 & $\begin{array}{l}\text { Glycolysis/Gluco- } \\
\text { neogenesis }\end{array}$ \\
\hline P26301 & K01689 & Enolase 1 & -2.870 & 7.313 & $\mathrm{D}$ & $48,290.9$ & ko00010 & $\begin{array}{l}\text { Glycolysis/Gluco- } \\
\text { neogenesis }\end{array}$ \\
\hline P04712 & K00695 & Sucrose synthase 1 & -2.545 & 5.83469 & $\mathrm{D}$ & $92,129.6$ & ko00500 & $\begin{array}{l}\text { Starch and sucrose } \\
\text { metabolism }\end{array}$ \\
\hline Q43704 & K02541 & $\begin{array}{l}\text { DNA replication } \\
\text { licensing factor } \\
\text { MCM3 }\end{array}$ & -2.539 & 5.811 & $\mathrm{D}$ & $85,694.0$ & ko03030 & $\begin{array}{l}\text { DNA replication } \\
\text { and repair }\end{array}$ \\
\hline P15719 & K00051 & $\begin{array}{l}\text { Malate dehydro- } \\
\text { genase [NADP], } \\
\text { chloroplastic }\end{array}$ & -2.475 & 5.560 & $\mathrm{D}$ & $47,429.3$ & ko01200 & $\begin{array}{l}\text { Carbon metabo- } \\
\text { lism }\end{array}$ \\
\hline P0C1M0 & K02115 & $\begin{array}{l}\text { ATP synthase } \\
\text { subunit gamma, } \\
\text { chloroplastic }\end{array}$ & -2.464 & 5.516 & $\mathrm{D}$ & $40,131.4$ & ko00195 & Photosynthesis \\
\hline P38560 & K01915 & $\begin{array}{l}\text { Glutamine } \\
\text { synthetase root } \\
\text { isozyme } 2\end{array}$ & -2.115 & 4.332 & $\mathrm{D}$ & $40,492.8$ & ko00250 & $\begin{array}{l}\text { Amino acid Bio- } \\
\text { synthesis }\end{array}$ \\
\hline $\mathrm{P} 18122$ & K03781 & Catalase isozyme 1 & -2.073 & 4.207 & $\mathrm{D}$ & $57,389.9$ & ko04146 & Oxidativ stress \\
\hline P02582 & K06759 & Actin-1 & -2.058 & 4.164 & $\mathrm{D}$ & $41,902.1$ & ko04514 & $\begin{array}{l}\text { Citoskeleton } \\
\text { metabolism }\end{array}$ \\
\hline Q6XZ79 & K00847 & Fructokinase-1 & -2.028 & 4.078 & $\mathrm{D}$ & $34,861.4$ & ko00500 & $\begin{array}{l}\text { Starch and sucrose } \\
\text { metabolism }\end{array}$ \\
\hline Q9SP22 & K08057 & Calreticulin & -1.854 & 3.616 & SLD & $48,052.8$ & ko04141 & $\begin{array}{l}\text { Protein folding and } \\
\text { sorting }\end{array}$ \\
\hline $\mathrm{O} 22424$ & K02987 & $\begin{array}{l}\text { 40S ribosomal } \\
\text { protein S4 }\end{array}$ & -1.832 & 3.561 & SLD & $30,130.6$ & ko03013 & Translation \\
\hline Q195N6 & K01006 & $\begin{array}{l}\text { Pyruvate, phos- } \\
\text { phate dikinase } \\
\text { regulatory protein, } \\
\text { chloroplastic } \\
\end{array}$ & -1.804 & 3.491 & SLD & $46,360.8$ & ko00710 & Carbon fixation \\
\hline B4G072 & K13227 & $\begin{array}{l}\text { DIMBOA UDP- } \\
\text { glucosyltrans- } \\
\text { ferase BX9 }\end{array}$ & -1.710 & 3.272 & SLD & $50,358.7$ & ko00402 & $\begin{array}{l}\text { Biosynthesis sec- } \\
\text { onday metabolites }\end{array}$ \\
\hline Q9ZSV1 & K24070 & $\begin{array}{l}\text { Poly [ADP-ribose] } \\
\text { polymerase } 1\end{array}$ & -1.698 & 3.244 & SLD & $111,614.5$ & ko03410 & Dna repair \\
\hline P80607 & K13379 & $\begin{array}{l}\text { Alpha-1,4-glucan- } \\
\text { protein synthase } \\
\text { [UDP-forming] }\end{array}$ & -1.654 & 3.148 & SLD & $41,717.1$ & ko00520 & $\begin{array}{l}\text { Carbohydrate } \\
\text { metabolism }\end{array}$ \\
\hline B4FAT0 & K11996 & $\begin{array}{l}\text { Adenylyltrans- } \\
\text { ferase and } \\
\text { sulfurtransferase } \\
\text { MOCS3 } 2\end{array}$ & -1.514 & 2.856 & SLD & $52,564.9$ & ko03013 & Translation \\
\hline Q8S4P4 & K11430 & $\begin{array}{l}\text { Histone-lysine } \\
\text { N-methyltrans- } \\
\text { ferase EZ3 }\end{array}$ & -1.498 & 2.824 & SLD & $102,388.1$ & ko00270 & $\begin{array}{l}\text { Amino acid } \\
\text { metabolism }\end{array}$ \\
\hline Q43272 & K00131 & $\begin{array}{l}\text { NADP-dependent } \\
\text { glyceraldehyde- } \\
\text { 3-phosphate } \\
\text { dehydrogenase }\end{array}$ & -1.432 & 2.698 & SLD & $53,773.0$ & ko00010 & $\begin{array}{l}\text { Glycolysis/Gluco- } \\
\text { neogenesis }\end{array}$ \\
\hline
\end{tabular}

Table 1. Differential abundant proteins (DAPs) in leaf tissue of high $p \mathrm{CO} 2$ samples comparing with those of normal $p \mathrm{CO} 2$ samples. Accession number, protein name, fold change expressed as Log (2) and absorbance, protein behavior KEGG orthology, molecular mass and metabolisms have been shown. Strongly accumulated and strongly depleted proteins are reported in bold. Details on mass spectrometry parameters for peptides for each identified proteins are reported in the Supplementary Table 2 STA: Strongly accumulated; STD: Strongly depleted; A: accumulated; D: Depleted; SLA: Slightly accumulated; SLD: Slightly depleted ${ }^{*}$ KEGG codes are developed in the Kanehisa Laboratories 


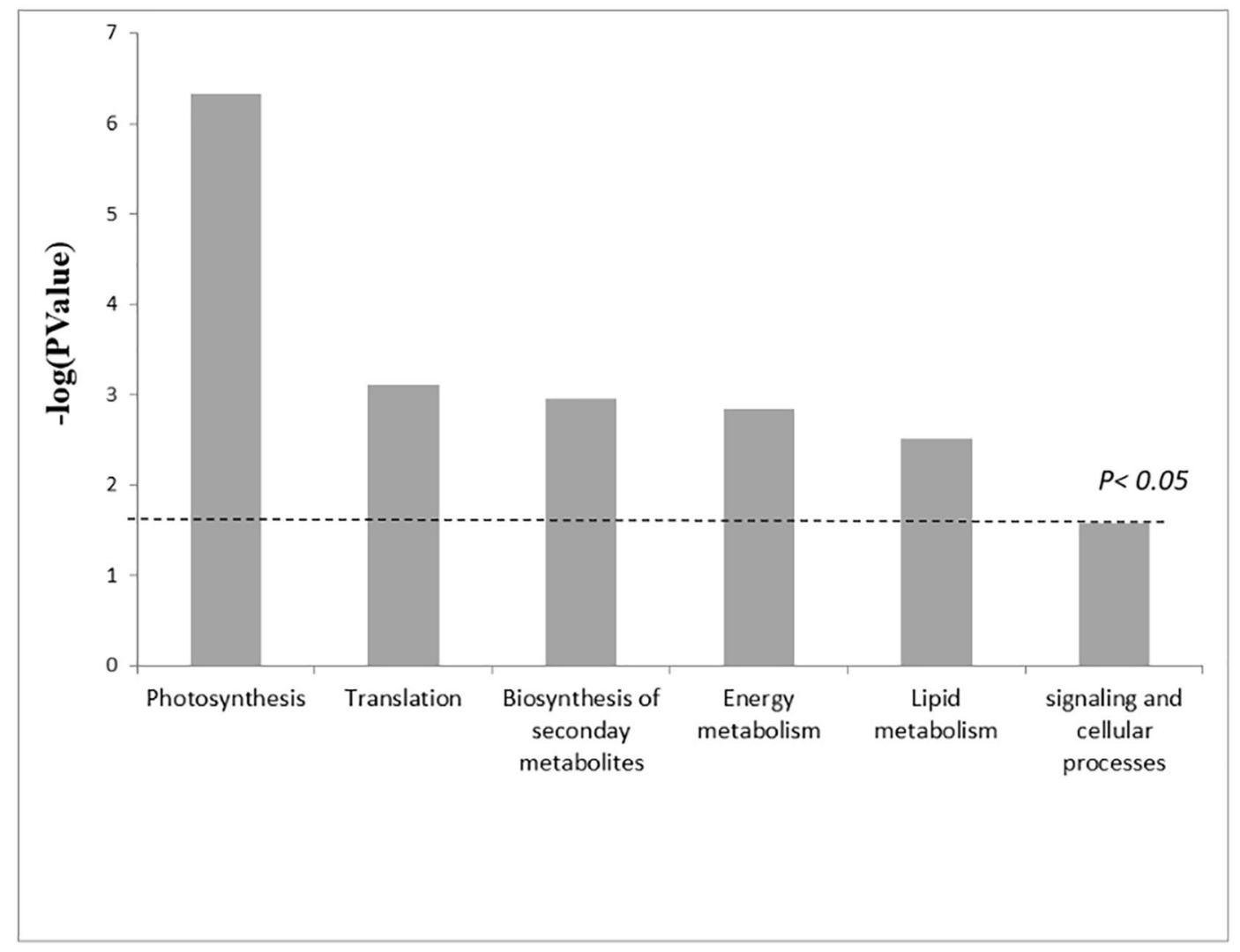

Figure 4. KEGG pathways where the differentially abundant proteins were enriched. The $x$-axis shows the proteins involved in the extended KEGG network and pathways. P values were calculated using a modified Fisher's exact test. Values above the threshold indicate $\mathrm{p}<0.05$. KEGG pathways are developed by Kanehisa Laboratories ${ }^{32}$.

Glyceraldehyde-3-phosphate dehydrogenase A, Fructose-bisphosphate aldolase and Enolase 1 were also depleted. The Malate synthase, that facilitates the glyoxylate cycle, the Pyruvate phosphate dikinase involved in the alternative glycolisis,, the Serine-threonine protein and many proteins involved in the amino acid metabolism are enriched under acidified conditions. Also the glutathione metabolism seems to be upregulated as the Glutathione transferases are accumulated under acidified condition.

Protein folding and turnover seemed also to be affected under acidified conditions as the Elongation factor 1-alpha, Chaperonin CPN60-2 and Ubiquitin-40S ribosomal protein S27a were strongly depleted. Proteins belonging to the cytoskeleton metabolism are affected by acidification such as Tubulin alpha-1 chain, Tubulin alpha-5 chain and Actin-1 (Table 1).

The leaf blades of $C$. nodosa growing under acidified conditions were shown to be almost $15 \%$ wider $(3.22 \pm 0.43 \mathrm{~mm})$ than those of plants living in normal $p \mathrm{CO}_{2}(2.76 \pm 0.52 \mathrm{~mm})$; epidermal cells have larger areas and thinner cell walls in high $p \mathrm{CO}_{2}$ leaves than those of normal $p \mathrm{CO}_{2}$ cells (Fig. 5). Leaves growing under acidified conditions have also larger parenchyma cells, lesser number of cells $/ \mathrm{mm}^{2}$ and thinner cell wall than those of normal $p \mathrm{CO}_{2}$ cells (Supplementary Table 4).

Schematic representation of DAPs involved in different metabolic pathways/cellular processes in Cymodocea nodosa to cope the environmental conditions at $\mathrm{CO}_{2}$ vents is reported in the Fig. 6.

\section{Discussion}

The comparative proteomics data showed that the long-term exposure to high $p \mathrm{CO}_{2}$ in the vicinity of volcanic vents strongly affected the inorganic carbon assimilation in leaves of Cymodocea nodosa as demonstrated by the significantly decreased levels of the key carbon metabolism enzymes. These results suggest that the chronic exposure of $\mathrm{C}$. nodosa to $\mathrm{CO}_{2}$-enriched volcanic emissions did not act positively toward carbon fixation, neither via Rubisco nor via PEPC, indicating a general depression of both inorganic carbon fixation pathways; even if the accumulation of Malate synthase and Pyruvate dikinase can pose the question whether or not seagrasses have a carbon concentrating mechanism, its existence to date is not proven and more evidence from "omics" is still required.

Our proteomic findings reinforce the results of a gene expression study carried out simultaneously on plants from the same populations, in which a significant down-regulation of the transcripts related to carbon metabolism, carbon uptake and carbohydrate metabolism were also found to be strongly down-regulated in the acidified leaves $^{25}$. Proteomics and trascriptomics thus demonstrate that the long-lasting exposure to the vents conditions 
a)

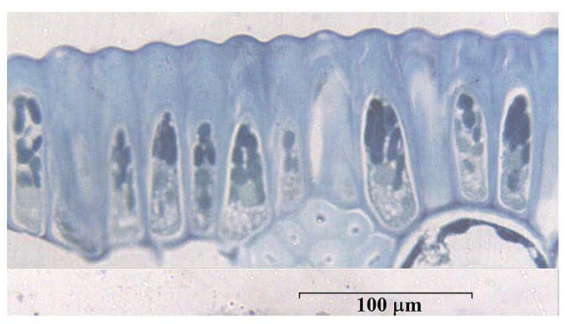

b)

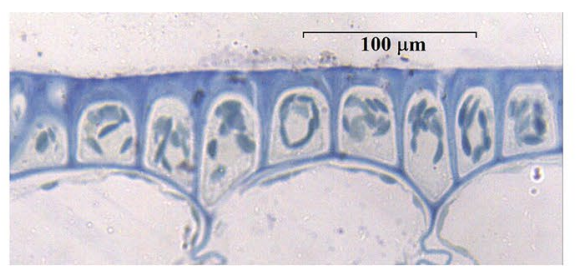

c)

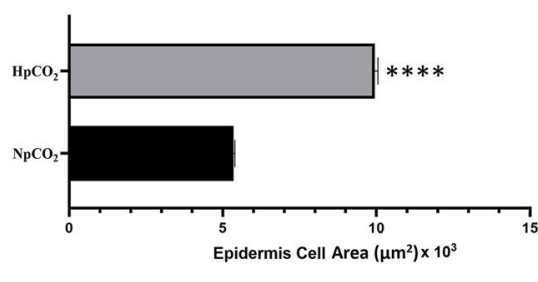

d)

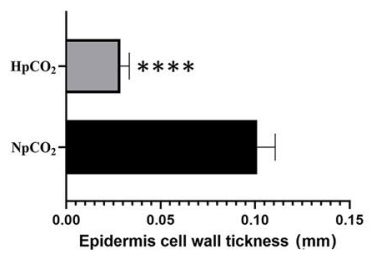

T-test : $\mathrm{HpCO}_{2}$ vs. $\mathrm{NpCO}_{2}$

$P$ value

$P$ value summary $<0.0001$

Significantly different $(P<0.05)$ ? Yes

One- or two-tailed $P$ value? $\quad$ Two-tailed

$\mathrm{t}, \mathrm{df}$

Number of pairs 40

Mean of differences (B - A) $\quad 4.605$

\begin{tabular}{ll}
$S D$ & of differences \\
\hline
\end{tabular}

SEM of differences 0.01713

$95 \%$ confidence interval $\quad 4.571$ to 4.640

R squared (partial eta squared) $\quad 0.9995$

\begin{tabular}{l|l} 
T-test : $\mathrm{HpCO}_{2}$ vs. $\mathrm{NpCO}_{2}$ & \\
\hline $\mathrm{P}$ value & $<0.0001$ \\
\hline $\mathrm{P}$ value summary & $* * * *$ \\
\hline Significantly different $(\mathrm{P}<0.05) ?$ & $\mathrm{Yes}$ \\
\hline One- or two-tailed $\mathrm{P}$ value? & Two-tailed \\
\hline $\mathrm{t}$ df & $\mathrm{t}=44.31, \mathrm{df}=39$ \\
\hline Number of pairs & 40 \\
\hline Mean of differences (B - A) & -0.07237 \\
\hline SD of differences & 0.01033 \\
\hline SEM of differences & 0.001633 \\
\hline 95\% confidence interval & -0.07567 to -0.06906 \\
\hline $\mathrm{R}$ squared (partial eta squared) & 0.9805
\end{tabular}

Figure 5. Cytological measurements of leaf epidermis of Cymodocea nodosa plants growing in normal and high $p \mathrm{CO}_{2}$ environments. Epidermal leaf cell microphotographs of C. nodosa growing in normal (a) and high (b) $p \mathrm{CO}_{2}$ environments. Boxplots $( \pm \mathrm{SD})$ showing the cell area (c) and cell wall thickness of epidermal thickness (d) of $C$. nodosa growing in normal and high $p \mathrm{CO}_{2}$ environments.

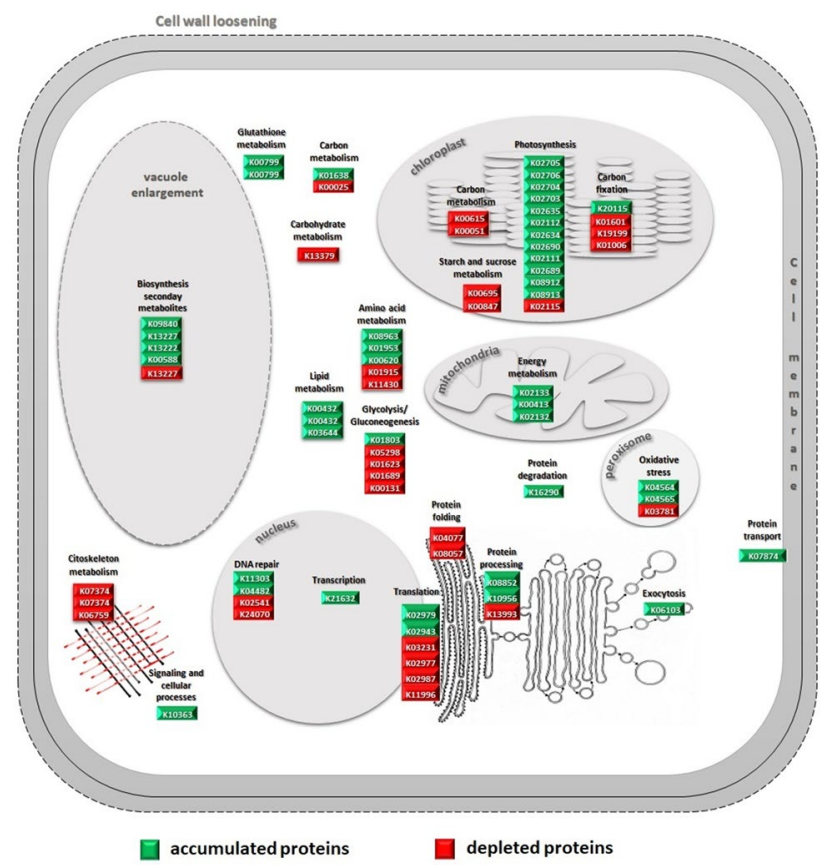

Figure 6. Schematic diagram of differentially expressed proteins belonging to metabolic pathways/cellular processes leading to the acclimation/tolerance of Cymodocea nodosa in volcanic vents. The acclimation strategy combines the reduction of carbon fixation, gluconeogenesis, carbohydrate metabolism and protein synthesis with increasing photophosphorylation, cell respiration and aminoacid metabolism to maintain the high energy demand for leaf expansion and elongation of the mesophyll cell; the cell expansion is accomplished by the cell wall loosening, the vacuole enlargement and the cytoskeleton remodeling. Proteins belonging the oxidative stress response pathway, the Gluthatione metabolism and the biosynthesis of secondary metabolites were also accumulated, suggesting that potential external stress factor other than $\mathrm{CO}_{2}$ are at play at the Vulcano submarine vents. Proteins and related KEGG codes, reported also in Table 1, are developed by Kanehisa Laboratories ${ }^{32}$. 
lead to the overall depression of the primary metabolisms, and are the probable cause of the reduction of the net plant productivity (NPP) and plant biomass found in plants growing in the vicinity of the vents ${ }^{8,25}$.

The metabolism of proteins is also negatively affected; previous proteomics studies of seagrasses living under several acute stressors or long-lasting disturbing factors also reported lower protein content linked to depletion of Rubisco ${ }^{28-30}$. Here we found that the lower protein contents is mainly due to an impaired protein synthesis at the post-transcriptional level in leaf tissue of plants under acidified conditions. Also protein function and turnover seems be the machinery that require an increasing energy demand.

Despite the strong depletion of the Calvin cycle proteins, a significant positive correlation between proteins related to the light reactions of photosynthesis and the exposure to high $p \mathrm{CO}_{2}$ was found, the same happening with some proteins belonging to photosystem II and photosystem I. High levels of Chl $a$ and significant increases in maximum electron transport rate and in compensation irradiance were previously found in C. nodosa grown under acidified conditions at this same volcanic $\mathrm{CO}_{2}$ vent, corroborating the hypothesis that acidification promotes the photosynthetic light reactions ${ }^{8}$. Moreover, we found that the energy metabolism from photophosphorylation and from oxidative phosphorylation are positively affected by high $p \mathrm{CO}_{2}$ exposure; the latter comes from leaf mitochondrial respiration which have been previously found to be up-regulated in the response to high $p \mathrm{CO} 2^{24,33}$. The observed depletion of the Calvin cycle proteins near the vents is likely to reflect a higher efficiency in the use of $\mathrm{CO}_{2}$ that would require a higher energy availability from the photosynthetic electron transport chain. On the other hand, a potential imbalance between the photosynthetic electron transport chain and the Calvin cycle reactions could also result in the formation of reactive oxygen species (ROS).

Increases in ROS may result from a number of other stress factors, and are usually associated with increases in the overall antioxidant capacity. The observed accumulation of antioxidant enzymes such as Peroxidases, Glutathione S-transferases, Superoxide dismutases and enzymes belonging the phenylpropanoid pathway has been well documented as defense responses of seagrasses to light stress and heavy metal toxicity ${ }^{27,29}$. The enhanced multi-enzyme antioxidant system indicates that vents conditions results in ROS production, triggering the response to scavenge $\mathrm{H}_{2} \mathrm{O}_{2}$ and maintaining the cell redox status. Taken all together, our results support the previously conveyed idea that potential external stress factors other than $\mathrm{CO}_{2}$ are at play at the Vulcano submarine vents, significantly affecting the plants' metabolic balance ${ }^{8,9,34}$.

The adaptive strategy that plants use to cope with vents condition also involves some morphological adjustments. If at the meadow level, $C$. nodosa lowered the density, biomass and below/aboveground biomass ratio at the acidified site ${ }^{8,9}$, at plant level, no significant differences in number of leaves per shoot (total mean number of leaves per shoot was $4 \pm 0.7$, data not shown) was found. Interestingly, we found that plants growing closer to the vents had shorter but wider leaf blades, epidermal cells with thinner cell walls and larger parenchyma cells. These morphological differences could indicate ecotypes, eventually selected by this extreme environment, but results from the population genetics carried out on the same sampling site showed no genetic differentiation and a high gene flow between $C$. nodosa plants growing at both the acidified and the control sites ${ }^{25}$. The morphological differences found should then be considered as a phenotypical response of C. nodosa to the pressure of the acidified environment. A similar pattern of leaf parameters was also recently described at the Vulcano $\mathrm{CO}_{2}$ vents by Vizzini et al. ${ }^{9}$. Our data support the hypothesis that under acidified conditions the cell expansion contributed more than cell division to the leaf expansion; following this assumption, leaf blades become shorter and wider than those grown in normal $p \mathrm{CO}_{2}$ condition. Further studies conducted on C. nodosa and Halodule wrightii demonstrated that an elevated $\mathrm{CO}_{2}$ concentration has effects on leaf mechanical resistence such as on the leaf anatomy and cell ultrastructures ${ }^{19,20}$. The authors reported that high $p \mathrm{CO}_{2}$-grown $C$. nodosa had an increased leaf-breaking force related to leaf growth; leaf width and cross-section area were larger under acidification in Halodule wrigtii, thus indicating that increased $\mathrm{CO}_{2}$ may manifest in large part at cellular level. Here we might conclude that the morphological traits have shown a positive correlation between mesophyll cell size and $\mathrm{pH}$ at $\mathrm{CO}_{2}$ venting sites, suggesting that wider leaves have a higher capacity to buffer $\mathrm{pH}$. Even if is demonstrated that exposure to elevate $\mathrm{pCO}_{2}$ alters plant structure by inducing change in rate of cell division and cell expansion in seed plants ${ }^{35}$, further investigation needs to elucidate whether C. nodosa growing in the vicinity of volcanic vents might ameliorate potential adverse effects on growth by means the mesophyll cell expansion and modified cell water uptake. In support of this idea, Ruocco et al. ${ }^{24}$ found that $C$. nodosa exposed to high $p \mathrm{CO}_{2}$ overexpressed transcripts encoding for enzymes that play an integral role in $\mathrm{pH}$ homoeostasis of the cells. Under this concept, mesophyll cells of $C$. nodosa might couple the ions homeostasis with increased water uptake to adjust the osmotic balance.

Moreover, specific molecular rearrangements seem to validate the hypothesis that high $p \mathrm{CO}_{2}$ led to larger cell size; biosynthesis of secondary metabolites appeared to be positively related to acidification and also to hormone-mediated response such ABA biosynthesis ${ }^{36-38}$. The actin-depolymerizing Factor 3 coupled with the Calcium-dependent protein kinase 2 (CDPK) have been found to modulate the plant cell shape through the regulation of the actin filament network in cytoskeleton ${ }^{39}$ and also to have a role in the re-organization of plant cytoplasm in response to a wide range of internal and external stimuli, suggesting a direct correlation between signal transduction and actin cytoskeleton reorganization in plants ${ }^{40,41}$. The strong depletion of tubulin and actin cytoskeleton constituents further support the suggestion that acidification affects the cytoskeleton dynamics and might trigger the modulation of cell enlargement and elongation in mesophyll cells. A pattern of thinner cell walls was also found in mesophyll epidermal cells of plants growing in the acidified site. Seagrasses possess a very different cell wall composition as well as proportion of polysaccharide and monosaccharides than terrestrial plants ${ }^{42}$; the modified cell wall structure and metabolism lead to an increase in the polyanionic character of seagrass cell wall ${ }^{43}$. It is well known that an acid cell wall is necessary for wall loosening to occur, thus promoting cell expansion and growth ${ }^{44}$; this mechanism is induced by the hormone auxin during cell elongation. In seagrasses, under normal conditions, the extracellular carbonic anhydrase mediates the conversion of $\mathrm{HCO}^{3-}$ to $\mathrm{CO}_{2}$ generating acid zones created by $\mathrm{H}^{+}$extrusion from the cytoplasm to the cell wall ${ }^{11}$; we can speculate that 
in an acidified environment the increased exogenous protons could, at least partially, substitute auxin in inducing cell enlargement. The thinner cell wall found in acidified epidermal cells of $C$. nodosa is likely to come from the cell elongation without ex novo biosynthesis of structural wall carbohydrates, due to the impaired primary metabolism and depressed carbon fixation; the lowered biomass of plants exposed to high $p \mathrm{CO}_{2}$ also indicates that leaf elongation occurred mainly by means of cell expansion. Thus, cell wall seems to be a critical player in response to acidification and further studies on the cell wall metabolism of $C$. nodosa growing near Vulcano $\mathrm{CO}_{2}$ vents are necessary.

In conclusion, proteomic analysis and cytological features evidence some physiological and structural adaptive traits of the seagrass Cymodocea nodosa growing in the vicinity of the Vulcano $\mathrm{CO}_{2}$ vents. This adaptation strategy combines the reduction of carbon fixation and gluconeogenesis with increasing photophosphorylation and cell respiration to maintain the high energy demand for leaf expansion and elongation of the mesophyll cell. Our results largely corroborate the findings of previous metabolic and transcriptomic studies carried out in the Vulcano vents, raising additional concerns on the use of volcanic vents as proxies for future acidification conditions. On the other hand, the specificities of the volcanic emissions also raise interesting questions and allow the investigation of pertinent physiological questions.

\section{Methods}

Sites description and plant sampling. Vulcano, the southernmost island of the Aeolian Archipelago, contains the most recently active center of submersed $\mathrm{CO}_{2}$ vents systems ${ }^{1}$. The most recent $\mathrm{CO}_{2}$ emissions originated from a volcanic activity on Vulcano occurred in 2002 has caused a series of gas explosions ${ }^{2}$. Most of the active submersed seeps are located along southern and western shores of Baia di Levante, where dispersed underwater leaks cover a $0.13 \mathrm{~km}^{2}$ shallow area $(1 \mathrm{~m}$ depth). Gas composition at the seeps consists of $99 \%$ of carbon dioxide and dissolved hydrogen sulphide from the seeps was undetectable at the sampling locations; seawater parameters, daily irradiance and $p \mathrm{CO}_{2}$ concentration at two sites were reported in Olivé et al. ${ }^{25}$.

For molecular analyses, $C$. nodosa samples (i.e., morphological individuals with two or more shoots) were collected at $5 \mathrm{~m}$ depth by SCUBA diving in the acidified site referred as high $p \mathrm{CO}_{2}$ environment $\left(38^{\circ} 25.057^{\prime} \mathrm{N}-14^{\circ} 57.599^{\prime} \mathrm{E}\right)$ and in a nearby site referred as normal $p \mathrm{CO}_{2}$ environment $\left(38^{\circ} 25^{\prime} 22^{\prime \prime} \mathrm{N}-14^{\circ} 57^{\prime}\right.$ $\left.82^{\prime \prime} \mathrm{E}\right)^{25}$. To assure the representation of the seagrass meadows in the study sites, sampling were performed along three grids of $20 \times 20 \mathrm{~m}$ each with the internal distance between sampled plants of $4-5 \mathrm{~m}$ to reach a total sampling of 15 individuals at each site. Once collected, epiphytes on leaf surface were rapidly and carefully removed by a razor, then leaves were rinsed in distilled water and immediately frozen in liquid nitrogen and kept at $-80^{\circ} \mathrm{C}$ until the protein extraction procedure described in Mazzuca et al..$^{30}$.

For the histological and cytological analyses adult leaves were selected from the 15 individuals at each sampling site, cleaned from the epiphytes, washed in sea water and fixed in $4 \%$ formalin in $0.15 \mathrm{M}$ phosphate buffer $\mathrm{pH} 7.2$ and stored refrigerated.

Extraction and purification of total protein from leaves. Frozen leaves were pooled forming 3 biological replicates, each composed by 5 individuals, because of the low amount of leaf tissue for each shoot. Leaf proteins were extracted by the multistep procedures ${ }^{28}$; for each extraction $1.4 \mathrm{~g}$ of pooled leaves were powdered in a mortar in liquid nitrogen until a fine powder was obtained. At this powder a volume of $10 \%$ TCA in acetone was added and centrifuged at 13,000 rpm for $5 \mathrm{~min}$ at $4{ }^{\circ} \mathrm{C}$. Subsequently, four washes were performed in $80 \%$ acetone in water. After centrifugation the pellet containing the precipitated proteins was dried at room temperature. Approximately $0.1 \mathrm{~g}$ of powdered tissue was dissolved in $0.8 \mathrm{ml}$ of phenol (buffered with Tris- $\mathrm{HCl}, \mathrm{pH} 8.0$, Sigma, St. Louis, MO, USA) and $0.8 \mathrm{ml}$ of SDS buffer (30\% sucrose, $2 \%$ SDS, $0.1 \mathrm{M}$ Tris-HCl, pH 8., 0,5\% 2-mercaptoetanol) in a $2 \mathrm{ml}$ microfuge tube. The samples were vortexed for $30 \mathrm{~s}$ and centrifuged at 13,000 rpm for 5 min to allow the solubilization of proteins in the phenol phase. The phenol phase was mixed with five volumes of $0.1 \mathrm{M}$ ammonium acetate in cold methanol, and the mixture was stored at $-20{ }^{\circ} \mathrm{C}$ for 30 min to precipitate proteins. Proteins were collected by centrifugation at 13,000 rpm for $5 \mathrm{~min}$. Two washes were performed with $0.1 \mathrm{M}$ ammonium acetate in cold methanol, and two with cold $80 \%$ acetone, and centrifuged at 13,000 rpm for $7 \mathrm{~min}$. The final pellet containing purified protein was dried and dissolved in Laemmli 1DE separation buffer overnight. Proteins were then quantified by measuring the absorbance at $595 \mathrm{~nm}$ according to the Bradford assay. Protein yield was calculated as milligrams of protein for $\mathrm{g}$ fresh tissue weight in three biological replicates at each site. For each replicate, two independent extractions were made. The relative abundances of proteins were calculated as mean \pm standard error $(n=6)$. A Student $t$-test was used to make pair-wise comparisons between normal $p \mathrm{CO}_{2}$ and high $p \mathrm{CO}_{2}$ samples. Unless otherwise noted, $\mathrm{p}$-levels of 0.05 were used as the threshold for statistical significance.

Electrophoresis of leaf proteins, protein in-gel digestion and mass spectrometry analyses. A gel was prepared at a concentration of $10 \%$ acrylamide/bisacrylamide, according to the method of ${ }^{45}$. The ratio of acrylamide/bisacrylamide was $12.5 \%$ in the running gel and $6 \%$ in the stacking gel. All biological replicates were heated for $5 \mathrm{~min}$ at $100{ }^{\circ} \mathrm{C}$ and $25 \mu \mathrm{g}$ of activated proteins were loaded on the each well in the gel. The electrophoretic run was carried out at $60 \mathrm{~mA}$ for the stacking gel and $120 \mathrm{~mA}$ in the running gel at power of $200 \mathrm{~V}$. The electrophoresis ran for an average time of $1 \mathrm{~h}$ and $15 \mathrm{~min}$. The gels were stained with Coomassie Blue overnight and subsequently destained with several changes of destaining solution (45\% methanol, $10 \%$ acetic acid). Digitalized images of the destained SDS-PAGEs were analyzed by the Quantity One 1-D Analysis Software (Bio-Rad Laboratories; Berkeley, California) to measure the optical densities at each lane of all biological replicates from both sites. The amount of protein at bands of 55,25, and $10 \mathrm{kDa}$ was done using the marker reference bands at 
75,50 , and $25 \mathrm{kDa}$ that contained 150, 750, and $750 \mathrm{ng}$ of proteins respectively (Fig. 1). Each lane of the same SDS-PAGE was divided in six slices from 200 to $10 \mathrm{kDa}$ and manually excised from the gel.

The CBB-stained gel slices from three biological replicates were destained and then processed for the reduction and alkylation steps by using dithiotreitol (DTT) and iodoacetamide (IAA), respectively ${ }^{46}$. Gel pieces were digested by Trypsin (Promega, Madison WI, USA) overnight at $37^{\circ} \mathrm{C}$ adding ammonium bicarbonate buffer to cover gel matrix. The extracted peptides from three independent biological replicates and two technical replicates were immediately processed for mass spectrometry analysis.

Tandem mass spectrophotometry (MS) analysis. A data-dependent tandem MS approach was carried out using a hybrid quadrupole-time-of-flight (Q-TOF) mass spectrometer (6550 IFunnel Q-TOF, Agilent Technologies, CA, USA), with a nano LC Chip Cube source (Agilent Technologies, CA, USA) according to Lucini and Bernardo ${ }^{47}$. The chip consisted of a 40-nL enrichment column (Zorbax 300SB-C18, $5 \mu \mathrm{m}$ pore size) and a $150 \mathrm{~mm}$ separation column (Zorbax 300SB-C18, $5 \mu \mathrm{m}$ pore size) coupled to an Agilent Technologies 1200 series nano/capillary LC system and controlled by the MassHunter Workstation Acquisition (version B.04).

A volume of $8 \mu \mathrm{L}$ was injected per run, loading peptides onto the trapping column at $4 \mu \mathrm{L} \mathrm{min}^{-1}$ in $2 \%(\mathrm{v} / \mathrm{v})$ acetonitrile and $0.1 \%(\mathrm{v} / \mathrm{v})$ formic acid. After enrichment, the chip was switched to separation mode and peptides were back flush eluted into the analytical column, during a $60 \mathrm{~min}$ acetonitrile gradient (from 3 to $90 \% \mathrm{v} / \mathrm{v}$ in $0.1 \%$ formic acid) at $0.6 \mu \mathrm{min}^{-1}$. The mass spectrometer was used in positive ion mode and MS scans were acquired over a mass range from 300 to $1700 \mathrm{~m} / \mathrm{z}$, at 4 spectra $\mathrm{s}^{-1}$.

Twelve precursor ions per scan were selected for auto-MS/MS, adopting an absolute threshold of 1000 and a relative threshold of $0.01 \%$, and enabling active exclusion after 2 spectra of the same precursor. Ramped collision energy was used for collision-induced decomposition, as a function of peptide charge.

Peptide identification from MS/MS spectra, proteins inference and validation were performed in Spectrum Mill MS Proteomics Workbench (Rev B.04; Agilent Technologies). Auto MS/MS spectra were extracted from raw data accepting a minimum sequence length of 3 amino acids and merging scans with the same precursor within a mass window of $\pm 0.4 \mathrm{~m} / \mathrm{z}$, in a time frame of $\pm 30 \mathrm{~s}$. Search parameters were Scored Peak Intensity (SPI) $\geq 50 \%$, precursor mass tolerance of $\pm 10 \mathrm{ppm}$ and product ions mass tolerance of $\pm 20 \mathrm{ppm}$. Carbamidomethylation of cysteine was set as fixed modification and trypsin was selected as enzyme for digestion, accepting 2 missed cleavages per peptide.

Considering that a species-specific proteome was not available, the proteome referring to viridiplantae in Uniprot was used; downloaded on April 2015, a total of 144,283 entries can be found according to this criterion.

Auto thresholds were used for peptide identification in Spectrum Mill, to achieve a target $1 \%$ false discovery rate. Label-free quantitation, using the protein summed peptide abundance, was carried out after identification.

Statistical analyses. The results were directly exported to Mass Profiler Professional B.04 (Agilent Technologies) for statistical analysis. Protein intensities were $\log 2$ normalized and fold-change analysis was carried out using a threshold of 3. Multivariate Partial Least Square Discriminant Analysis (PLS-DA) was then carried out ( $\mathrm{N}$-fold validation, using $\mathrm{N}=3$ and 10 repeats). The PLS-DA class prediction model loading, i.e. the plot of the weight for each protein in the model within the latent vectors, was used to select those proteins being more discriminant in class prediction (those having a score of above +0.2 rather than below -0.2 ). These proteins were exported from the covariance structures in the PLS-DA hyperspace and further discussed.

Preparation of samples and histological analyses. For each individual, several $5 \times 5 \mathrm{~mm}$ pieces of six fixed leaves were cutted and washed in $0.15 \mathrm{M}$ phosphate buffer three times for $10 \mathrm{~min}$; subsequently leaf pieces were treated with $1 \%$ osmium tetraoxide in phosphate buffer. Leaf pieces were then dehydrated trough the increasing concentration of ethanol solutions. Dehydrate samples were then imbedded in epoxy resin, obtained by mixing Epon 812 -Araldite and ethanol $(1: 1, \mathrm{v} / \mathrm{v})$ for $4-5 \mathrm{~h}$ at $4{ }^{\circ} \mathrm{C}$ and then embedded in pure resin overnight at room temperature. The embedded samples were polymerized in an oven at $60^{\circ} \mathrm{C}$ for 3 days; then each sample was cut in $0.2 \mathrm{~mm}$ thick sections through the ultramicrotome. The sections were transferred onto slides and stained with Methylene Blue. At least ten sections for each leaf sample were observed and photographed at $100 \mathrm{X}$ magnification and digitalized using Image J open source software. A measurement bar of $100 \mu \mathrm{m}$ as a reference scale was added to the images obtained for subsequent analysis using CellProfiler open source software (Broad Institute; country). The areas of 20 cells per section of the epidermis and parenchyma were measured and the thickness of the epidermis and parenchyma cell wall was also measured and a $100 \times 100 \mu \mathrm{m}$ scale square. The measurements obtained were divided into two datasets of all the samples of the two sites; the first dataset with the comparison of the mean values of the cell area and the second dataset with the comparison of the average values of the wall thickness. Significance of values from both datasets were made by $\mathrm{t}$-student test using the GraphPad Prism 8 software.

Received: 9 May 2020; Accepted: 24 November 2020

Published online: 18 December 2020

\section{References}

1. Tassi, F. et al. Low-pH waters discharging from submarine vents at Panarea Island (Aeolian Islands, southern Italy) after the 2002 gas blast: Origin of hydrothermal fluids and implications for volcanic surveillance. Appl. Geochem. 24, 246-254 (2009). 
2. Boatta, F. et al. Geochemical survey of Levante Bay, Vulcano Island (Italy), a natural laboratory for the study of ocean acidification. Mar. Pollut. Bull. 73, 485-494. https://doi.org/10.1016/j.marpolbul.2013.01.029 (2013).

3. Hall-Spencer, J. M. et al. Volcanic carbon dioxide vents show ecosystem effects of ocean acidification. Nature 454, 96-99 (2008).

4. Ricevuto, E., Kroeker, K. J., Ferrigno, F. \& Gambi, M. C. Spatio-temporal variability of polychaete colonization at volcanic $\mathrm{CO}_{2}$ vents indicates high tolerance to ocean acidification. Mar. Biol. 161, 2909-2919. https://doi.org/10.1007/s00227-014-2555-y (2014).

5. Ricevuto, E., Vizzini, S. \& Gambi, M. C. Ocean acidification effects on stable isotope signatures and trophic interactions of polychaete consumers and organic matter sources at a $\mathrm{CO}_{2}$ shallow vent system. J. Exp. Mar. Biol. Ecol. 468, 105-117. https://doi. org/10.1016/j.jembe.2015.03.016 (2015).

6. Foo, S.A., Byrne, M., Ricevuto, E., Gambi, M.C. The Carbon Dioxide Vents of Ischia, Italy, A Natural System to Assess Impacts of Ocean Acidification on Marine Ecosystems: An Overview of Research and Comparisons with Other Vent Systems. In Oceanography and Marine Biology An Annual Review. S. J. Hawkins, A. J. Evans, A.C. Dale, L. B. Firth, I. P. Smith eds. Taylor \& Francis Group, 56 (2018).

7. Mutalipassi, M. et al. Ocean acidification alters the responses of invertebrates to wound-activated infochemicals produced by epiphytes of the seagrassPosidonia oceanica. J. Exp. Mar. Biol. Ecol. 530-531, 151435 (2020).

8. Apostolaki, E. T., Vizzini, S., Hendriks, I. E. \& Olsen, Y. S. Seagrass ecosystem response to long-term high $\mathrm{CO}_{2}$ in a Mediterranean volcanic vent. Mar. Environ. Res. 99, 9-15 (2014).

9. Vizzini, S., Apostolaki, E. T., Ricevuto, E., Polymenakou, P. \& Mazzola, A. Plant and sediment properties in seagrass meadows from two Mediterranean $\mathrm{CO}_{2}$ vents: Implications for carbon storage capacity of acidified oceans. Mar. Environ. Res. 146, 101-108 (2019).

10. Beer, S., Björk, M., Beardall, J. Acquisition of carbon in marine plants. In: John Wiley \& Sons eds. Photoshynthesis in the Marine Environment. Wiley Blackwell, Iowa, USA. pp: 95-124 (2014).

11. Beer, S., Björk, M., Hellblom, F. \& Axelsson, L. Inorganic carbon utilization in marine angiosperms (seagrasses). Funct. Plant Biol. 29, 349-354 (2002).

12. Koch, M., Bowes, G., Ross, C. \& Zhang, X. H. Climate change and ocean acidification effects on seagrasses and marine macroalgae. Glob. Change Biol. 19, 103-132. https://doi.org/10.1111/j.1365-2486.2012.02791.x (2013).

13. Zimmerman, R. C., Kohrs, D. G., Steller, D. L. \& Alberte, R. S. Impacts of $\mathrm{CO}_{2}$ enrichment on productivity and light requirements of eelgrass. Plant Physiol. 115, 599-607. https://doi.org/10.1104/pp.115.2.599 (1997).

14. Garrard, S. L. \& Beaumont, N. J. The effect of ocean acidification on carbon storage and sequestration in seagrass beds; a global and UK context. Mar. Pollut. Bull. 86, 138-146 (2014).

15. Hendriks, I. E., Duarte, C. M. \& Alvarez, M. A. Vulnerability of marine biodiversity to ocean acidification: a meta-analysis. Estuar. Coast. Shelf Sci. 86, 157-164 (2010).

16. Zimmerman, R. C., Hill, V. J. \& Gallegos, C. L. Predicting effects of ocean warming, acidification, and water quality on Chesapeake region eelgrass. Limnol. Oceanogr. 60(2015), 1781-1804 (2015).

17. Pacella, S. R., Cheryl, A. B., George, G. W., Rochelle, G. L. \& Burke, H. Seagrass habitat metabolism increases short-term extremes and long-term offset of CO2 under future ocean acidification. PNAS 115(15), 3870-3875 (2018).

18. Russell, B. D., Connell, S. D., Uthicke, S. \& Hall-Spencer, J. M. Future seagrass beds: can increased productivity lead to increased carbon storage?. Mar. Pollut. Bull. 73, 463-469 (2013).

19. de los Santos, C. B., Godbold, J. A. \& Solan, M. Short-term growth and biomechanical responses of the temperate seagrassCymodocea nodosato $\mathrm{CO}_{2}$ enrichment. Mar. Ecol. Prog. Ser. 572, 91-102 (2017).

20. Schneider, G. et al. Structural and physiological responses of Halodule wrightii to ocean acidification. Protoplasma 255, 629-641 (2018).

21. Radoglou, K. M. \& Jarvis, P. G. The effects of $\mathrm{CO} 2$ enrichment and nutrient supply on growth morphology and anatomy of Phaseolus vulgaris L seedlings. Ann. Bot. 70, 245-256 (1992).

22. Epron, D., Liozon, R. \& Mousseau, M. Effects of elevated $\mathrm{CO}_{2}$ concentration on leaf characteristics and photosynthetic capacity of beech (Fagus sylvatica) during the growing season. Tree Physiol. 16, 425-432 (1995).

23. Lin, J., Jach, M. E. \& Ceulemans, R. Stomatal density and needle anatomy of Scots pine (Pinus sylvestris) are affected by elevated $\mathrm{CO}_{2}$. New Phytol. 150, 665-674 (2001).

24. Ruocco, M. et al. Genome-wide transcriptional reprogramming in the seagrassCymodocea nodosa under experimental ocean acidification. MolEcol 26, 4241-4259. https://doi.org/10.1111/mec.14204 (2017).

25. Olivé, I. et al. Linking gene expression to productivity to unravel long- and short-term responses of seagrasses exposed to $\mathrm{CO}_{2}$ in volcanic vents. Sci. Rep. 7, 42278 (2017).

26. Procaccini, G. et al. Depth-specific fluctuations of gene expression and protein abundance modulate the photophysiology in the seagrassPosidonia oceanica. Sci. Rep. 7, 42890. https://doi.org/10.1038/srep42890 (2017).

27. Kumar, M. et al. Proteome analysis reveals extensive light stress response reprogramming in the seagrassZostera muelleri (Alismatales, Zosteraceae) metabolism. Frontiers Plant Sci. 7, 2023 (2017).

28. Piro, A. et al. The modulation of leaf metabolism plays a role in salt tolerance of Cymodocea nodosa exposed to hypersaline stress in mesocosms. Front Plant Sci. 6, 464 (2015).

29. Dattolo, E. et al. Acclimation to different depths by the marine angiosperm Posidonia oceanica: transcriptomic and proteomic profiles. Front. Plant Sci. 4, 195. https://doi.org/10.3389/fpls.2013.00195 (2013).

30. Mazzuca, S. et al. Seagrass light acclimation: 2-DE protein analysis in Posidonia leaves grown inchronic low light conditions. J. Exp. Mar. Biol. Ecol. 374, 113-122 (2009).

31. Schwanhäusser, B. et al. Global quantification of mammalian gene expression control. Nature 473, 337-342 (2011).

32. Kanehisa, M. \& Goto, S. KEGG: Kyoto encyclopedia of genes and genomes. Nucleic Acids Res. 28, 27-30 (2000).

33. Watanabe, C. K. et al. Effects of elevated $\mathrm{CO} 2$ on levels of primary metabolites and transcripts of genes encoding respiratory enzymes and their diurnal patterns in Arabidopsis thaliana: possible relationships with respiratory rates. Plant Cell Physiol. 55(2), 341-357. https://doi.org/10.1093/pcp/pct185 (2014).

34. Lauritano, C. et al. Response of key stress-related genes of the seagrassPosidonia oceanica in the vicinity of submarine volcanic vents. Biogeosciences 12, 4947-4971 (2015).

35 Neha, S., Gokhale, S. P. \& Kumar, B. A. Effect of elevated $\left[\mathrm{CO}_{2}\right]$ on cell structure and function in seed plants. Clim. Change Environ. Sustain. 2, 69-104. https://doi.org/10.5958/2320-642X.2014.00001.5 (2014).

36. Iuchi, S. et al. Regulation of drought tolerance by gene manipulation of 9-cis-epoxycarotenoid dioxygenase, a key enzyme in abscisic acid biosynthesis in Arabidopsis. Plant J. 27, 325-333. https://doi.org/10.1046/j.1365-313x.2001.01096.x (2001).

37. Endo, A. et al. Drought induction of Arabidopsis 9-cis-epoxycarotenoid dioxygenase occurs in vascular parenchyma cells. Plant Physiol. 147, 1984-1993 (2008).

38 Toh, S. et al. High temperature-induced abscisic acid biosynthesis and its role in the inhibition of gibberellins action in Arabidopsis seeds. Plant Physiol. 146, 1368-1385 (2008).

39. Dong, C. H. et al. ADF proteins are involved in the control of flowering and regulate F-actin organization, cell expansion, and organ growth in Arabidopsis. Plant Cell 13, 1333-1346 (2001).

40. Vantard, M. \& Blanchoin, L. Actin polymerization processes in plant cells. Curr. Opin. Plant Biol. 5(6), 502-506 (2002).

41. Smertenko, A. P. et al. Ser6 in the maize actin-depolymerizing factor, ZmADF3, is phosphorylated by a calcium-stimulated protein kinase and is essential for the control of functional activity. Plant J. 14(2), 187-193 (1988). 
42. Webster, J. \& Stone, B. A. Isolation, structure and monosaccharide composition of the wall of vegetative parts of Heterozostera tasmanica (Martens ex Aschers) den Hartog. Aquat. Bot. 47, 39-52 (1994).

43. Olsen J.L., Rouzé, P., Verhelst, B., Lin, Y.-C., Bayer, T., Collen, J., Dattolo, E., De Paoli, E., Dittami, S., Maumus, F., et al. The genome of the seagrass Zostera marina reveals angiosperm adaptation to the sea. Nature 530, 331-335 (2016) https://doi.org/10.1038/natur e16548.

44. Brummel, D. A. Cell wall acidification and its role in Auxin-stimulated growth. J. Exp. Bot. 37(2), 270-276 (1986).

45. Laemmli, U. K. Cleavage of structural proteins during the assembly of the head of bacteriophage T4. Nature 227, 680-685 (1970).

46. Shevchenko, A., Tomas, H., Havlis, J., Olsen, J. V. \& Mann, M. In-gel digestion for mass spectrometric characterization of proteins and proteomes. Nat. Protoc. 1, 2856-2860 (2007).

47. Lucini, L. \& Bernardo, L. Comparison of proteome response to saline and zinc stress in lettuce. Front. Plant Sci. https://doi. org/10.3389/fpls.2015.00240 (2015).

\section{Acknowledgements}

This study received Portuguese national funds from FCT-Foundation for Science and Technology through project UIDB/04326/2020 and is also a contribution to the FCT projects HighGrass, (PTDC/MAR-EST/3687/2012) and GrassMet (PTDC/MAR-EST/4257/2014). During the sampling campaign and data analysis, AP was supported by a STSM fellowship within the ESF COST Action "Seagrass Productivity: from genes to ecosystem management", coordinated by Rui Santos. The authors deeply thank Daniela Perrotta and Nicodemo Passalacqua for their valuable technical and logistic support for the histological sample preparation.

\section{Author contributions}

S.M. and J.S. coordinated the manuscript writing, S.M., A.P., J.S., R.S. conceived and designed the experiments, S.M., A.P., R.S., J.S., I.O., I.B. and M.M.C. participated to the sampling campaign and the field work, A.P., L.B., and L.L. performed the mass spectrometry analysis, A.P., L.B. and I.A.A. performed the bioinformatics and statistical analyses. S.M. and A.P. performed the cytological measurements. All Authors reviewed the manuscript.

\section{Competing interests}

The authors declare no competing interests.

\section{Additional information}

Supplementary information is available for this paper at https://doi.org/10.1038/s41598-020-78764-7.

Correspondence and requests for materials should be addressed to S.M.

Reprints and permissions information is available at www.nature.com/reprints.

Publisher's note Springer Nature remains neutral with regard to jurisdictional claims in published maps and institutional affiliations.

(c) (i) Open Access This article is licensed under a Creative Commons Attribution 4.0 International License, which permits use, sharing, adaptation, distribution and reproduction in any medium or format, as long as you give appropriate credit to the original author(s) and the source, provide a link to the Creative Commons licence, and indicate if changes were made. The images or other third party material in this article are included in the article's Creative Commons licence, unless indicated otherwise in a credit line to the material. If material is not included in the article's Creative Commons licence and your intended use is not permitted by statutory regulation or exceeds the permitted use, you will need to obtain permission directly from the copyright holder. To view a copy of this licence, visit http://creativecommons.org/licenses/by/4.0/.

(C) The Author(s) 2020 